\title{
Productivity Differences under Alternative Tenurial Contracts in Agriculture and Access to Credit: Evidence from Rural West Bengal, India
}

\author{
A. Laha and P.K. Kuri *
}

\begin{abstract}
Since the days of Marshall (1890), sharecropping has been the subject of academic discourse concerned with static efficiency and its impact on agricultural innovations and productive efficiency. Whilst exploring the theoretical and empirical debates on sharecropping efficiency, this paper makes a renewed attempt to examine the productivity differences under alternative modes of cultivation. Based on a primary survey of 203 households encompassing 303 agricultural holdings in rural West Bengal, this paper also attempts to identify factors which are responsible for productivity differences under alternative tenurial contracts. The empirical evidence and subsequent statistical analysis confirms the equal efficiency hypothesis of Cheung (1969) and asserts that variation in productive efficiency among tenurial contracts is due to the variation in input used in agriculture where the access to credit is observed to play a significant role in input utilization and in achieving productive efficiency in agriculture.
\end{abstract}

\section{Introduction}

Agrarian institution of land tenancy has received a wide academic attention over centuries and across various countries of the world. Share tenancy, a particular form of agricultural tenancy, is debated on the ground of efficiency in improving productivity. In the first formal attempt in the debate, Marshall (1890) considered share tenancy as an inefficient mode of cultivation where resources are sub-optimally utilized. Long before the writings of Marshall, Smith (1776) considered the institution of "matayer" (sharecropper) results in inefficient allocation of resource, which, in turn, acts as a hindrance to agricultural development. In a similar line of argument, Marquis of Mirabeau argued that "share tenancy is a deplorable method of cultivation, the daughter of necessity and mother of misery" (quoted in Basu, 2002). In fact, all economists until Johnson (1950) have considered sharecropping to be a "practice which is hurtful to the whole society". Countering Marshallian inefficiency argument, Johnson (1950) advocated that

The authors are, respectively, Assistant Professor and Associate Professor, Department of Commerce and Department of Economics, The University of Burdwan, India. Corresponding author's email: arindamlaha2004@yahoo.co.in 
the tenant could be induced to apply the efficient level of input by landlord with constant monitoring the tenant's cultivation, leases out land in parcels and renew the contracts only after satisfactory performance. In a study, Cheung (1969) formalized the Johnson's argument and showed that share tenancy is no less efficient than the owner cultivation or fixed-rent tenancy. Bardhan and Srinivasan (1971) and Jaynes (1982) challenged the theoretical formulation of Cheung (1969) and established the conventional Marshallian inefficient argument by extending the conventional partial equilibrium analysis into a more general framework. In a series of papers, Bagchi (1975; 1976; 1982) criticized the models of both Cheung (1969), and Bardhan and Srinivasan (1971), as they are based on unrealistic arguments of competitive models. Like theoretical contributions, empirical studies showed divergent opinions regarding the question on whether the observable magnitudes of inputs and outputs differ systematically between sharecropped lands on the one hand and land that is owned or rented on fixed-rent terms on the other. The studies that provide empirical support to the Marshallian inefficiency hypothesis include Bharadwaj (1974), Bell (1977), Shaban (2000), and Chattopadhayay (1979). On the other hand, the studies supported Cheung's equal-efficiency argument includes Rao (1971), Chakravarty and Rudra (1973), Dwivedi and Rudra (1973a, 1973b), and Nabi (1986). In addition, some studies showed mixed results (Hossain, 1977 and Bliss and Stern, 1982). Interestingly, the observed differences in productivity under alternative mode of cultivation have been explained and explored in the literature in several ways like risk sharing (Cheung, 1969; Stiglitz, 1974; Dutta, 1983; Pant, 1980; Rao, 1971), screening (Hallagan, 1978) and non-marketable factors like technological-knowhow (Reid, 1976), managerial ability (Bell and Zusman, 1979; Kuri, 2003), bullocks (Bliss and Stern, 1982), family labour (Pant, 1983), and credit (Jaynes, 1982). Under this backdrop, using the empirical evidence of rural West Bengal, this paper examines the productivity differences under alternative modes of cultivation. Further, the paper attempts to identify the factors which are responsible for productivity differences under alternative tenurial contracts.

The outline of the paper is as follows. After introductory section, section 2 presents the data sources and methodological framework of the study. Section 3 deals with the nature of tenurial contracts in the study villages. A comparison of the productivity differences under alternative forms of cultivation practices are presented in section 4 by using Fisher's t-test. Section 5 provides explanations on the observed differences in productivity in terms of variation of the utilization of inputs like credit, fertilizer and materialized inputs. The section 6 presents the concluding remarks. 


\section{Data Sources and Methodology}

The study is based on a field survey in rural West Bengal in the year 2006-07. Taking into consideration the extent and the incidence of tenancy practices, out of 18 districts of West Bengal, the district of Burdwan was selected for the survey ${ }^{1}$. In the second stage, among the 31 blocks under Burdwan district, one block, namely, Raina I was selected on the consideration of the existence of diversified nature of agricultural practices and the co-existence of various land tenurial contracts. Again, Raina I block was stratified into two distinct agro climatic zones-one, developed zone with canal irrigation and the other, underdeveloped zone with rain-fed agriculture. From the developed zone, the villages, namely, Saktia and Anguna were chosen, whereas the villages namely, Dhamash and Boro were chosen from the underdeveloped zone under the same criteria ${ }^{2}$. Once villages are selected, 203 sampling units, the farm-households were chosen using stratified random sampling of farmers with probability being proportionate to the farm size so that the sample can represent the actual proportions of all the five strata of the farmers. It is to be noted that 203 households operate over 303 agricultural holdings under alternative mode of cultivation. Our empirical analysis is restricted to 303 holdings. The farm households were divided into five categories covering landless agricultural labourers, marginal farmers (less than 2.5 acre), small farmers (2.5-5 acre), medium farmers (5-10 acre) and large farmers (above 10 acre).

The productivity differences under alternative forms of cultivation are tested through Fisher's t-test. The appropriate test statistics for testing the productivity differences are presented in the appendix.

\section{Nature of Tenurial Contracts in the Surveyed Villages}

Tenancy is an agrarian institution in which landlord leases out his land to a tenant who cultivates the land and gives a fixed proportion of the total output (in cash or in kind) to the landlord. The most important and widely used tenurial practices are fixed rent tenancy and sharecropping. Sharecropping is

1 The district of Burdwan comprised of $7.83 \%$ of total leased in land (wholly and partly) in the state of West Bengal. Only two hill districts, Darjeeling and Jalpaiguri, comprised of $12.11 \%$ and $21.28 \%$ of leased in area respectively are above Burdwan district. However, terms of leasing in the hill districts are distinct from other districts of West Bengal (Agricultural Census, 2000-01). Thus the choice of the district of Burdwan as our survey area is purely based on the ground of the dominant practice of land leasing for crop cultivation in the state.

2 The selection of district, block and villages are based on a-priori information and hence it is purposive and non-random. For further details about the selection of sampling units based on primary and secondary data, see Laha (2009). 
again practiced with two varieties: sharecropping with cost sharecropping and without cost sharecropping arrangement ${ }^{3}$. Coexistence of all three forms of contracts is widely prevalent in our surveyed villages. Out of 203 households surveyed, we have come across 106 households who are involved in different types of tenancy contracts. The classification of households under alternative forms of tenancy (Table 1) reveals the fact that landless and marginal farmers are predominantly ( $87.73 \%$ of cases) lease in land from large landlords. About $52.22 \%$ of total surveyed households are engaged in lease in land market. Out of 106 cases, 37 cases are reported to practice under fixed rent tenancy; whereas in 33 cases $^{4}$ sharecropping is the mode of tenurial contract. But, sharecroppers are not a homogeneous group of tenants. There is wide variation in the sharing of output between landlord and tenant under sharecropping mode of cultivation. The dominant practice (44\% of cases) is 1/2:1/2 crop sharing where landlord bears a part of total cost. If the tenant bears the full cost of cultivation, the output sharing ration becomes 3/4:1/4 and $2 / 3: 1 / 3$. Thus, there is a negative association between cost sharing and output sharing.

It is interesting to note that the choice of tenurial contracts has an important bearing on cropping pattern in agricultural production (Table 2). Fixed rent tenancy is observed to be inclined upon the production of capital intensive crop (potato and boro cultivation). This is because wealthy tenants, who generally prefer fixed rent form of tenancy, can take the whole risk associated with cultivation. On the other hand, sharecropping tenants are mostly interested in cultivating those crops (amanswarna paddy, til and mustard cultivation) which can meet their subsistence requirements and are labor intensive in nature.

3 Under fixed rent tenancy, the landlord leases out the land to the tenant and in return asks for a fixed rental payment. The sharecropping is a form of tenurial contact under which tenant leases in land from the landlord and shares the output under predetermined contractual arrangement. The sharecropping is again of two types. The cost sharing sharecropping under which the landlord shares the cost of factor of production usually in the same proportion as the share of output. On the other hand, under the arrangements of the sharecropping without cost sharing tenants bear the full cost of production and the proportion of output share to the landlord is usually smaller than under cost-sharing arrangement. Inclusion of cost sharing arrangement in our analysis is particularly relevant in view of the widespread prevalence of the arrangement as a part of the tenancy contract, which is a striking new phenomenon in Indian agriculture (Bardhan, 1984).

424 cases are associated with pure sharecropping (i.e. no cost sharing) and 9 cases are associated with cost sharecropping. 
5

Table 1: Distribution of types of tenancy under different categories of households

\begin{tabular}{lcccccc}
\hline Types of contracts & \multicolumn{7}{c}{ Category of households } & \\
\cline { 2 - 7 } & AGL & MRF & SMF & MID & LF & ALL \\
\hline Fixed rent tenancy & 10 & 24 & 1 & 1 & 1 & 37 \\
& $(28.57)$ & $(41.38)$ & $(11.11)$ & $(33.33)$ & $(100.00)$ & $(34.90)$ \\
Pure sharecropping & 6 & 13 & 4 & 1 & 0 & 24 \\
& $(17.14)$ & $(22.41)$ & $(44.44)$ & $(33.33)$ & $(0.00)$ & $(22.64)$ \\
Cost sharing & 5 & 4 & 0 & 0 & 0 & 9 \\
& $(14.29)$ & $(6.90)$ & $(0.00)$ & $(0.00)$ & $(0.00)$ & $(8.49)$ \\
Both fixed rent and & 14 & 17 & 4 & 1 & 0 & 36 \\
sharecropping & $(40.00)$ & $(29.31)$ & $(44.44)$ & $(33.33)$ & $(0.00)$ & $(33.96)$ \\
& & & & & & \\
Total & 35 & 58 & 9 & 3 & 1 & 106 \\
& $(100.00)$ & $(100.00)$ & $(100.00)$ & $(100.00)$ & $(100.00)$ & $(100.00)$ \\
\hline
\end{tabular}

Source: Field Survey 2006-07

Note: $A G L=$ Agricultural labourers, $M R F=$ Marginal farmers, $S M F=S m a l l$ farmers, $\mathrm{MDF}=$ Medium farmers, $\mathrm{LF}=$ Large farmers

Table 2: $\quad$ Contractual arrangements and the nature of cropping pattern

\begin{tabular}{|c|c|c|c|c|}
\hline $\begin{array}{l}\text { Cropping } \\
\text { pattern }\end{array}$ & $\begin{array}{c}\text { Owner } \\
\text { cultivation }\end{array}$ & $\begin{array}{l}\text { Fixed rent } \\
\text { tenancy }\end{array}$ & $\begin{array}{c}\text { Sharecropping } \\
\text { tenancy }\end{array}$ & $\begin{array}{c}\text { Cost } \\
\text { sharecropping } \\
\text { tenancy }\end{array}$ \\
\hline Aman paddy & $154(49.20)$ & $11(11.23)$ & $34(57.64)$ & $29(78.38)$ \\
\hline Boro paddy & $30(9.58)$ & $27(27.55)$ & $2 \quad(3.39)$ & $\begin{array}{ll}0 & (0.00)\end{array}$ \\
\hline Potato & $55(17.58)$ & $47(47.96)$ & (1.69) & $1 \quad(2.70)$ \\
\hline Mustard & $31 \quad(9.90)$ & $4 \quad(4.08)$ & $5 \quad(8.47)$ & $4 \quad(10.81)$ \\
\hline Til & $30 \quad(9.58)$ & (5.10) & 13 (22.03) & $3(8.11)$ \\
\hline Wheat & $4(1.28)$ & $(1.02)$ & $2 \quad(3.39)$ & $(0.00)$ \\
\hline Others & $9(2.88)$ & $3 \quad(3.06)$ & $2 \quad(3.39)$ & $\begin{array}{ll}0 & (0.00)\end{array}$ \\
\hline All crops & $313(100.00)$ & $98(100.00)$ & $59(100.00)$ & $37(100.00)$ \\
\hline
\end{tabular}

Source: Field Survey 2006-07

\section{Empirical Results and Discussion}

The main objective of this section is to compare productivity differences under alternative modes of cultivation. To serve the purpose, we have taken production per bigha as a measure of productivity. The test of the differences in productivity of the alternative modes of cultivation has been carried through Fishers-t test by testing the following propositions.

Proposition I: Tenants are equally efficient in resource allocation as owner cultivators. 
Proposition II: Fixed rent tenants are as efficient in resource allocation as owner cultivators.

Proposition III: If sharecroppers are free to choose the amount of land and labor used in production they will allocate less labor, will have lower intensity of cultivation and lower output per acre compared to owner cultivation and fixed rent tenants.

The productivity comparison has been carried out crop and plot wise separately for three sets of data pertaining to owner land tenant farms specially to compare productivity in (i) pure owner and pure tenant farms along with owner-cum-tenant farms, (ii) owner farms and the farms under fixed rent tenancy, and (iii) sharecropped farms and the farms under fixed rent tenancy.

\section{Test Results of Productivity Comparison in Owner and Tenant Farms}

A comparison between output per bigha of the owner-operated and tenanted farms is conducted chronologically for the amanswarna $a^{5}$ cultivation, paddy cultivation and, finally, for all crops taken together to test Proposition I (Table 3). It is found that the average productivity of pure owner and pure tenant are 7.11 and 6.70 quintals (all crops), 7.03 and 6.61 quintals (paddy), 6.88 and 6.26 quintals (amanswarna paddy) per bigha respectively. F-test, presented in same table III, has been carried out to explain the variation of the average productivities of land in the two sub-samples which helps us to select test statistic for testing mean difference. In general', our ' $t$ ' test result indicates no significant difference in the average productivity of land between owner and pure tenant farms and of owner cum tenant farms. Thus the overall conclusion supports Cheung's equal-efficient hypothesis that tenant farms are as efficient as owner farms.

\footnotetext{
5 Amanswarna is the local name of a particular paddy variety. It is the most preferred HYV variety in terms of coverage of area in our study villages.

6 The only exception is found in amanswarna paddy mean yields on owner cultivated farms are found significantly higher than tenant farms at $8 \%$ level of significance.
} 
7

Table 3: $\quad$ Test results for differences in productivity of pure owner pure tenant and owner cum tenant cultivators

\begin{tabular}{|c|c|c|c|c|c|c|c|}
\hline Category & Crop & $\begin{array}{c}\text { Nature of } \\
\text { plot }\end{array}$ & $\begin{array}{c}\text { No. of } \\
\text { plots }\end{array}$ & $\begin{array}{c}\text { Mean } \\
\text { yield (in } \\
\text { quintals) }\end{array}$ & $\begin{array}{l}\text { Standard } \\
\text { Deviation }\end{array}$ & $\begin{array}{c}\mathbf{F} \\
\text { Value }\end{array}$ & $\begin{array}{c}\mathbf{T} \\
\text { Value }\end{array}$ \\
\hline \multirow{6}{*}{$\begin{array}{l}\text { Pure } \\
\text { owner and } \\
\text { Pure } \\
\text { tenant }\end{array}$} & All crop & Pure Owner & 77 & 7.1135 & 2.4327 & 3.8038 & -0.613 \\
\hline & & Pure Tenant & 59 & 6.69836 & 4.7446 & & $(0.5408)$ \\
\hline & Paddy & Pure Owner & 77 & 7.02977 & 1.5832 & 1.0940 & -1.335 \\
\hline & & Pure Tenant & 36 & 6.6088 & 1.5137 & & $(0.1846)$ \\
\hline & Amanswarna & Pure Owner & 73 & 6.87814 & 1.6123 & 1.4923 & -1.803 \\
\hline & & Pure Tenant & 28 & 6.2617 & 1.3198 & & $(0.0744)$ \\
\hline \multirow{6}{*}{$\begin{array}{l}\text { Owner } \\
\text { cum } \\
\text { tenant }\end{array}$} & All crop & Owned Plot & 63 & 7.7393 & 3.0588 & 2.6686 & -0.5308 \\
\hline & & Tenanted Plot & 63 & 8.1311 & 4.9967 & & $(0.5965)$ \\
\hline & Paddy & Owned Plot & 55 & 7.0868 & 2.4434 & 1.3061 & 1.0296 \\
\hline & & Tenanted Plot & 55 & 6.6360 & 2.1380 & & $(0.3055)$ \\
\hline & Amanswarna & Owned Plot & 36 & 6.4754 & 1.6767 & 1.3652 & 0.57756 \\
\hline & & Tenanted Plot & 36 & 6.2272 & 1.9591 & & $(0.5654)$ \\
\hline
\end{tabular}

Source: Field Survey 2006-07

Note: The statistical analysis has been made using GRETL statistical package

The figure in parenthesis indicates P-value at two tailed test.

\section{Productivity Differences in Owner Cultivation and Fixed Rent Tenancy}

Proposition II is tested by comparing the average performance of pure owner and pure fixed rent tenants and of owner cum fixed rent tenants (Table 4). The difference in average productivity of pure owner and pure fixed rent tenants is found much wider in the analysis of all crop cultivation (7.11 and 9.04 quintals), than the paddy (7.03 and 7.76 quintals) and amanswarna cultivation (6.87 and 6.8 quintals). Similar conclusion can be drawn in case of owner cum fixed rent tenants. The overall conclusion in paddy and amanswarna cultivation confirms proposition II that fixed rent contract is no more inefficient than owner cultivation. Overall (in all crop cultivation), the mean productivity of fixed rent tenant is found statistically higher than owner plots of land. 
8

Table 4: $\quad$ Test results for differences in productivity of pure owner-pure fixed rent and owner cum fixed rent tenants

\begin{tabular}{|c|c|c|c|c|c|c|c|}
\hline Category & Crop & $\begin{array}{l}\text { Nature of } \\
\text { plot }\end{array}$ & $\begin{array}{l}\text { No. of } \\
\text { plots }\end{array}$ & $\begin{array}{l}\text { Mean yield } \\
\text { (in quintals) }\end{array}$ & $\begin{array}{l}\text { Standard } \\
\text { Deviation } \\
\end{array}$ & $\begin{array}{c}\text { F } \\
\text { Value } \\
\end{array}$ & $\begin{array}{c}\text { T } \\
\text { Value }\end{array}$ \\
\hline \multirow{6}{*}{$\begin{array}{l}\text { Pure } \\
\text { owner- } \\
\text { pure fixed } \\
\text { rent }\end{array}$} & All & Owner & 77 & 7.1135 & 2.4327 & 5.772 & -1.636 \\
\hline & crops & Fixed rent & 26 & 9.04266 & 5.8446 & & $(0.105)$ \\
\hline & Paddy & Owner & 77 & 7.02977 & 1.5832 & 3.486 & -1.490 \\
\hline & & Fixed rent & 11 & 7.7581 & 0.84800 & & $(0.140)$ \\
\hline & Aman & Owner & 73 & 6.87814 & 1.6123 & 16.25 & 0.301 \\
\hline & swarna & Fixed rent & 5 & 6.8 & 0.40000 & & $(0.765)$ \\
\hline \multirow{6}{*}{$\begin{array}{l}\text { Owner } \\
\text { cum fixed } \\
\text { rent }\end{array}$} & All & Owned Plot & 43 & 8.12917 & 3.3352 & 4.557 & -2.939 \\
\hline & crops & $\begin{array}{l}\text { Fixed rent } \\
\text { Plot }\end{array}$ & 43 & 11.6532 & 7.1195 & & $(0.004)$ \\
\hline & Paddy & Owned Plot & 23 & 8.01921 & 2.9639 & 1.945 & 0.485 \\
\hline & & $\begin{array}{l}\text { Fixed rent } \\
\text { Plot }\end{array}$ & 23 & 7.65065 & 2.1251 & & $(0.630)$ \\
\hline & Aman & Owned Plot & 5 & 7.28024 & 0.59326 & 3.091 & -0.894 \\
\hline & swarna & $\begin{array}{l}\text { Fixed rent } \\
\text { Plot }\end{array}$ & 5 & 7.76 & 1.0431 & & $(0.397)$ \\
\hline
\end{tabular}

Source: Field Survey 2006-07

Note: The statistical analysis has been made using GRETL statistical package

The figure in parenthesis indicates P-value at two tailed test.

\section{Productivity Differences in Fixed Rent and Sharecropping Tenancy}

Proposition III is tested by comparing the average productivity performance in case of sharecropper and pure fixed rent tenant and more specifically sharecropper cum fixed rent cultivators (as in Table 5 and 6). Empirical evidence suggests that the average productivity of fixed rent tenants is significantly lower than that of pure sharecroppers. Similar analysis ${ }^{7}$ in respect of sharecropper cum fixed rent cultivators also provides strong support to our result that fixed rent tenancy is an efficient mode of production vis-à-vis sharecropping arrangements (Table 5). On the other hand, productivity comparison of cost sharecropper and fixed rent tenants suggest a significantly higher productivity in fixed rent tenants as compared to that of cost sharecroppers (Table 6). Thus our results refute the earlier empirical findings of many of the studies (Cheung, 1969; Bliss and Stern, 1982) that sharecropping tenants are as productive as fixed rent tenants.

7 No analysis is carried out in case of amanswarna cultivation due to insufficient number of observations. 
Table 5: $\quad$ Test results for differences in productivity of pure sharecropper-fixed rent and pure sharecropper cum fixed rent tenants

\begin{tabular}{|c|c|c|c|c|c|c|c|}
\hline Category & Crop & Nature of plot & $\begin{array}{c}\text { No. of } \\
\text { plots }\end{array}$ & $\begin{array}{c}\text { Mean yield } \\
\text { (in } \\
\text { quintals) } \\
\end{array}$ & $\begin{array}{l}\text { Standard } \\
\text { Deviation }\end{array}$ & $\begin{array}{c}\text { F } \\
\text { Value }\end{array}$ & $\begin{array}{c}\text { T } \\
\text { Value }\end{array}$ \\
\hline \multirow{6}{*}{$\begin{array}{l}\text { Pure } \\
\text { sharecropper- } \\
\text { fixed rent }\end{array}$} & All & Fixed rent & 74 & 11.167 & 7.0037 & 10.13 & -7.078 \\
\hline & crops & Sharecropping & 77 & 5.138 & 2.2010 & & $(0.0000)$ \\
\hline & Paddy & Fixed rent & 35 & 7.573 & 1.8911 & 1.264 & -3.722 \\
\hline & & Sharecropping & 65 & 6.202 & 1.6821 & & $(0.0003)$ \\
\hline & Aman & Fixed rent & 10 & 7.28 & 0.9004 & 3.617 & -3.208 \\
\hline & swarna & Sharecropping & 60 & 6.124 & 1.7124 & & $(0.0020)$ \\
\hline \multirow{4}{*}{$\begin{array}{l}\text { Pure } \\
\text { sharecrop } \\
\text { cum fixed } \\
\text { rent }\end{array}$} & All & Fixed rent Plot & 36 & 12.7053 & 6.9715 & 10.025 & -6.105 \\
\hline & crops & $\begin{array}{l}\text { Sharecropping } \\
\text { Plot }\end{array}$ & 36 & 5.26648 & 2.2018 & & $(0.000)$ \\
\hline & Paddy & Fixed rent Plot & 8 & 7.91774 & 0.63996 & 3.0712 & -2.551 \\
\hline & & $\begin{array}{l}\text { Sharecropping } \\
\text { Plot }\end{array}$ & 8 & 6.75333 & 1.1215 & & $(0.023)$ \\
\hline
\end{tabular}

Source: Field Survey 2006-07

Note: The statistical analysis has been made using GRETL statistical package

The figure in parenthesis indicates P-value at two tailed test.

Table 6: Test results for differences in productivity of cost sharecropper-fixed rent and cost sharecropper cum fixed rent tenants

\begin{tabular}{|c|c|c|c|c|c|c|c|}
\hline Category & Crop & Nature of plot & $\begin{array}{l}\text { No. of } \\
\text { plots }\end{array}$ & $\begin{array}{c}\text { Mean yield } \\
\text { (in } \\
\text { quintals) }\end{array}$ & $\begin{array}{l}\text { Standard } \\
\text { Deviation }\end{array}$ & $\begin{array}{c}\mathbf{F} \\
\text { Value }\end{array}$ & $\begin{array}{c}\text { T } \\
\text { Value }\end{array}$ \\
\hline \multirow[t]{3}{*}{$\begin{array}{l}\text { cost } \\
\text { sharecropper- } \\
\text { fixed rent }\end{array}$} & $\begin{array}{l}\text { All } \\
\text { crops }\end{array}$ & $\begin{array}{l}\text { Fixed rent } \\
\text { Cost } \\
\text { sharecropping }\end{array}$ & $\begin{array}{l}74 \\
30\end{array}$ & $\begin{array}{c}11.167 \\
5.20496\end{array}$ & $\begin{array}{l}7.0037 \\
1.6836\end{array}$ & 17.30 & $\begin{array}{l}-6.851 \\
(0.000)\end{array}$ \\
\hline & Paddy & $\begin{array}{l}\text { Fixed rent } \\
\text { Cost } \\
\text { sharecropping }\end{array}$ & $\begin{array}{l}35 \\
29\end{array}$ & $\begin{array}{l}7.57326 \\
5.90247\end{array}$ & $\begin{array}{l}1.8911 \\
1.6976\end{array}$ & 1.241 & $\begin{array}{c}-3.684 \\
(0.0005)\end{array}$ \\
\hline & $\begin{array}{l}\text { Aman } \\
\text { swarna }\end{array}$ & $\begin{array}{l}\text { Fixed rent } \\
\text { Cost } \\
\text { sharecropping }\end{array}$ & $\begin{array}{l}10 \\
27\end{array}$ & $\begin{array}{c}7.28 \\
5.85648\end{array}$ & $\begin{array}{c}0.90037 \\
1.7417\end{array}$ & 3.742 & $\begin{array}{c}-3.237 \\
(0.0026)\end{array}$ \\
\hline \multirow[t]{2}{*}{$\begin{array}{l}\text { cost } \\
\text { sharecropper } \\
\text { cum fixed } \\
\text { rent }\end{array}$} & $\begin{array}{l}\text { All } \\
\text { crops }\end{array}$ & $\begin{array}{l}\text { Fixed rent Plot } \\
\text { Cost } \\
\text { sharecropping } \\
\text { Plot }\end{array}$ & $\begin{array}{l}21 \\
21\end{array}$ & $\begin{array}{l}12.7062 \\
5.61485\end{array}$ & $\begin{array}{l}7.7883 \\
1.5643\end{array}$ & 24.787 & $\begin{array}{l}-4.091 \\
(0.000)\end{array}$ \\
\hline & Paddy & $\begin{array}{l}\text { Fixed rent Plot } \\
\text { Cost } \\
\text { sharecropping } \\
\text { Plot }\end{array}$ & $\begin{array}{l}3 \\
3\end{array}$ & $\begin{array}{l}7.76667 \\
7.20889\end{array}$ & $\begin{array}{l}0.4792 \\
0.0154\end{array}$ & 968.77 & $\begin{array}{l}-2.015 \\
(0.114)\end{array}$ \\
\hline
\end{tabular}

Source: Field Survey 2006-07

Note: The statistical analysis has been made using GRETL statistical package

The figure in parenthesis indicates P-value at two tailed test.

Thus, our empirical results, on the one hand, support Cheung's equalefficient hypothesis that tenanted farms are equally efficient as owner cultivation. But, productive efficiency varies among several tenurial contracts. 
Fixed rent tenancy is observed to be most efficient in enhancing agricultural productivity and thus superior to sharecropping mode of cultivation.

\section{Explanation of the Observed Differences in Agricultural Productivity}

In this section, an attempt has been made to provide an explanation of our empirical findings that productive efficiency varies according to the modes of cultivation. In general, fixed rent tenancy is observed to be superior to all other tenurial contracts in achieving allocative efficiency in agriculture. In other words, sharecropping system is sub-optimal in allocating inputs in agricultural vis-à-vis fixed rent tenancy. A part of the explanation may lie in variation of the utilization of inputs like fertilizer and materialized inputs ${ }^{8}$ and the access to credit. The role of credit availability is crucial as it not only explain the variation of two above mentioned inputs, but also can able to explain the coexistence of alternative modes of cultivation in the survey area. The empirical investigation addresses the following questions- (i) whether coexistence of alternative modes of cultivation have any impact on the use of these inputs i.e. fertilizer, materialized inputs and credit, and (ii) how far the difference in credit availability is related to the utilization of fertilizer and materialized inputs faced by different tenurial groups.

\section{Use of Fertilizer and Materialized Inputs under Alternative Modes of Cultivation}

The results of comparison in the use of fertilizer and materialized input in paddy cultivation under alternative modes of cultivation are presented in Table 7.

The following points can be noted from Table 7:

Owner and Tenant Households: Pure tenant households apply more materialized inputs per bigha of land as compared to pure owner cultivators. The difference in the use of materialized input is significant at $6 \%$ level of significance. In owner-cum-tenant cultivators, fertilizer and materialized inputs are intensively applied in tenant plot in comparison to owner plot, but the result is significant only in case of materialized input. Short term lease with the threat of eviction has been found as effective means to enforce the tenants to intensively cultivate their land.

8 Here we have only considered these two inputs as they are related to credit availability. 
11

Table 7: $\quad$ Test results for differences in the use of fertilizer and materialized inputs under alternative forms of cultivation

\begin{tabular}{|c|c|c|c|c|c|c|c|c|}
\hline \multirow[t]{2}{*}{ Category } & \multirow[t]{2}{*}{ Form } & \multirow[t]{2}{*}{ Obs. } & \multicolumn{3}{|c|}{ Fertilizer } & \multicolumn{3}{|c|}{ Material input } \\
\hline & & & Mean & $\mathbf{T}$ & Sig. & Mean & $\mathbf{T}$ & Sig. \\
\hline Pure owner (PO) \& & $\mathrm{PO}$ & 77 & 416.30 & 0.0535 & 0.9574 & 1350.39 & 1.9526 & 0.0534 \\
\hline Pure Tenant (PT) & PT & 36 & 418.25 & & & 1635.13 & & \\
\hline Owner (OP) cum & $\mathrm{OP}$ & 55 & 394.10 & -0.9096 & 0.3651 & 1288.7 & -2.587 & 0.0110 \\
\hline Tenant (TP) & $\mathrm{TP}$ & 55 & 425.07 & & & 1620.3 & & \\
\hline Sharecropper (SC) \& & $\mathrm{SC}$ & 65 & 361.31 & -4.8237 & 0.0000 & 1244.71 & -6.374 & 0.0000 \\
\hline Fixed rent (FR) & FR & 35 & 525.57 & & & 2304.43 & & \\
\hline Sharecropper (SP) cum & SP & 8 & 335.17 & -2.41 & 0.0303 & 922.085 & -5.169 & 0.0001 \\
\hline Fixed rent $(\mathrm{FP})$ & FP & 8 & 507.05 & & & 2089.68 & & \\
\hline Costsharecropper (CS) & $\mathrm{CS}$ & 29 & 331.72 & -5.4937 & 0.0000 & 1155.01 & -6.674 & 0.0000 \\
\hline \& Fixed rent (FR) & FR & 35 & 525.57 & & & 2304.43 & & \\
\hline Costsharecropper (SP) & SP & 3 & 293.11 & -1.8211 & 0.1427 & 758.111 & -7.773 & 0.0015 \\
\hline cum Fixed rent (FP) & FP & 3 & 527.14 & & & 2519.19 & & \\
\hline
\end{tabular}

Source: Field Survey 2006-07

Note: The statistical analysis has been made using GRETL statistical package

Sharecropping and Fixed Rent Tenants: Fixed rent tenants applied more fertilizer and materialized inputs in their leased in land compared to that of sharecropper. The result is systematic and significant both in case of pure fixed tenant and pure sharecropper, and in fixed rent cum sharecropper households.

Cost Sharecropper and Fixed Rent Tenants: Utilization of fertilizer and materialized inputs is found to be significantly ${ }^{9}$ lower in case of cost sharecropping tenants as compared to fixed renters. The result is in stark contrast to other empirical finding that landlords can ensure efficient resource allocation in sharecropping contracts by sharing costs with their tenants in the same proportion as the rental share (Bliss and Stern, 1982).

Availability of Credit under Alternative Modes of Cultivation: In the section, the study investigated the role of the availability of credit under alternative modes of cultivation and also its role in the variation of the utilization of fertilizer and materialized inputs. Sources of credit are broadly divided into three categories: formal credit, informal credit, and total credit (both formal and informal credit). Difference in the availability of credit ${ }^{10}$ under alternative modes of cultivation is presented in the Table 8 .

9 The result is not significant in case of fertilizer use by cost sharing cum fixed rent tenant due to insufficient number of observations.

10 Only credit utilized for production purpose is considered in the analysis. 
12

Table 8: $\quad$ Test result for difference in the availability of credit under alternative modes of cultivation

\begin{tabular}{|c|c|c|c|c|c|c|c|c|}
\hline \multirow[t]{2}{*}{ Category } & \multirow[t]{2}{*}{ Form } & \multirow[t]{2}{*}{ Obs. } & \multicolumn{2}{|c|}{ Formal loan } & \multicolumn{2}{|c|}{ Informal loan } & \multicolumn{2}{|c|}{ Total loan } \\
\hline & & & Mean & $\mathbf{t}$ & Mean & $\mathbf{T}$ & Mean & T (Sig.) \\
\hline Pure owner (PO) \& & $\mathrm{PO}$ & 77 & 529.689 & -3.287 & 575.664 & 2.172 & 1105.3 & 0.403 \\
\hline Pure Tenant (PT) & PT & 59 & 85.5046 & $(0.001)$ & 1130.31 & $(0.032)$ & 1215.8 & $(0.687)$ \\
\hline Owner (OP) cum & OP & 63 & 600.675 & 0.586 & 361.005 & -2.376 & 961.68 & -1.246 \\
\hline Tenant (TP) & $\mathrm{TP}$ & 63 & 489.435 & $(0.559)$ & 771.732 & $(0.019)$ & 1261.2 & $(0.215)$ \\
\hline Sharecropper (SC) \& & $\mathrm{SC}$ & 77 & 121.315 & -3.362 & 260.122 & -5.636 & 381.44 & -7.527 \\
\hline Fixed rent $(\mathrm{FR})$ & FR & 74 & 725.634 & $(0.001)$ & 1492.95 & $(0.000)$ & 2218.6 & $(0.000)$ \\
\hline Sharecropper (SP) cum & SP & 36 & 138.423 & -2.307 & 280.895 & -4.289 & 419.32 & -5.802 \\
\hline Fixed rent $(\mathrm{FP})$ & FP & 36 & 769.786 & $(0.024)$ & 1570.14 & $(0.000)$ & 2339.9 & $(0.000)$ \\
\hline Costsharecropper (CS) & $\mathrm{CS}$ & 30 & 140.452 & -3.179 & 250.075 & -5.523 & 390.53 & -7.313 \\
\hline$\&$ Fixed rent $(\mathrm{FR})$ & FR & 74 & 725.634 & $(0.002)$ & 1492.95 & $(0.000)$ & 2218.6 & $(0.000)$ \\
\hline Costsharecropper (CP) & $\mathrm{CP}$ & 21 & 200.646 & -1.92 & 248.891 & -3.377 & 449.54 & -4.764 \\
\hline cum Fixed rent (FP) & FP & 21 & 933.969 & $(0.062)$ & 1791.17 & $(0.002)$ & 2725.1 & $(0.000)$ \\
\hline
\end{tabular}

Source: Field Survey 2006-07

Note: The statistical analysis has been made using GRETL statistical package

Some important observations from the Table 8 can be drawn in this regard. Pure owner utilizes a higher amount of formal loan as compared to pure tenant. The conclusion also remains valid in case of owner-cum-tenant household in the sense that formal credit is mostly appropriated in owned plot as compared to tenanted plot. The result of difference in formal credit utilization is found to be statistically significant in case of pure owner-pure tenant households, but not in case of owner-cum-tenant households. Just the opposite conclusion can be drawn in case of informal loan. Here tenant household appropriates more informal credit as compared to owner household. The result becomes stronger with an additional evidence that owner-cum-tenant household utilizes more informal credit in tenanted holding as compared to owned holding. It is to be noted that a larger dependence of pure tenant on informal loan for production purpose is reflected in the analysis of total formal and informal loan (Table 8). Here also pure tenants appropriate more loan from formal as well as informal sources than pure owner households. However, the result is not statistically significant. Fixed rent tenants are observed to utilize much more credit from all sources of credit (i.e. formal, informal, and total loan) than the sharecroppers. The result is found consistent among sharecropper cum fixed rent tenant households. Moreover, fixed rent tenants are also found to utilize more credit than the cost sharing sharecroppers. The result is statistically significant irrespective of 
nature of credit viz., formal, informal and total. The same conclusion in all sources of credit also remains valid in case of fixed rent-cum-cost sharecropping household. It can be concluded from the above analysis that owner cultivators utilize more of formal credit than the pure tenant while pure tenants use more informal credit compared to owner cultivators. Moreover, fixed rent tenants, in general, utilize more credit than the tenants under other tenurial contracts.

Interestingly, the pattern of the credit utilization (Table 8) is observed to have direct impact on the use of fertilizer and materialized inputs in agriculture (Table 8). Pure tenant household applied more fertilizer and materialized inputs as compared to pure owner household due to greater access of production loan from formal and informal sources. Again, both these inputs are intensively applied by fixed rent tenants as compared to pure sharecropper or cost sharecropper. This may be because of the greater access of production loan by fixed rent tenants as compared to pure sharecropper or cost sharecropper.

\section{Conclusions}

The empirical evidence of this study suggests that productive efficiency varies according to the modes of cultivation. Our result based on Fisher's t-test supports Cheung's equal efficient hypothesis that tenant cultivation is as efficient as owner cultivation in the aggregative analysis of all crops and paddy cultivation. A productivity comparison of owner-cumtenants in their owned plots and leased in land plots strengthen our earlier observation that there is no systematic and significant difference in productivity between owned plots and tenanted plots of land. However, the study refutes the proposition that sharecropping tenants are as productive as fixed rent tenants. Fixed rent tenancy is observed to be superior to all other tenurial contracts in achieving allocative efficiency in agriculture. In other words, sharecropping is proven to be inefficient in optimal utilization of inputs vis-à-vis fixed rent tenancy. Even the cost sharing arrangement between landlords and tenants fail to ensure efficiency in sharecropping contract as compared to fixed rent tenancy. Explanations are also given in support of the observed output differences in terms of the utilization of inputs like credit, fertilizer and materialized inputs. The access to credit is observed to play a significant role in input utilization and in achieving productive efficiency in agriculture. 


\section{References}

Bagchi, A.K. (1975). Cropsharing Tenancy in Agriculture: A Rejoinder, Economic and Political Weekly, 10(30):1131-1133.

Bagchi, A.K. (1976). Crop Sharing Tenancy and Neo-Classical Economics, Economic and Political Weekly, 11(3):74-83.

Bagchi, A.K. (1982). The Political Economy of Underdevelopment, Cambridge: Cambridge University Press.

Bardhan, P.K. (1984). Land, Labor, and Rural Poverty: Essays in Development Economics. Oxford University Press.

Bardhan, P.K. and T.N. Srinivasan (1971). Crop Sharing Tenancy in Agriculture: A Theoretical and Empirical Analysis, American Economic Review, 61:48-64.

Basu, K (2002). Analytical Development Economics: The Less Developed Economy Revisited. Oxford University Press.

Bell, C. (1977). Alternative Theories of Sharecropping: Some Tests Using Evidence from Northeast India, Journal of Development Studies, 13(4):317-346.

Bell. C. and and P. Zusman (1979). New Approaches to the Theory of Rental Contracts in Agriculture. Development Research Centre, World Bank, Washington D.C.

Bharadwaj, K. (1974). Production Conditions in Indian Agriculture: A Study Based on Farm Management Surveys. Cambridge: Cambridge University Press.

Bliss, C.J. and N.H. Stern (1982). Palanpur: The Economy of an Indian Village. Oxford: Clarendon Press.

Chakravarty, A. and A. Rudra (1973). Economic Effects of Tenancy-Some Negative Results. Economic and Political Weekly, 8(28):1239-1246.

Chattopadhyay, M. (1979). Relative Efficiency of Owner and Tenant Cultivation: A Case Study, Economic and Political Weekly, 14(39):A93-A96. 
Cheung, S.N.S. (1969). The Theory of Share Tenancy. Chicago: University of Chicago Press,

Department of Agriculture and Cooperation (2001). Agricultural Census, 2000-01, Agricultural Census Division, Department of Agriculture and Cooperation, Government of India.

Dutta, S.K. (1983). Sharecropping as a "Second-Best" Forms of Tenancy in Traditional Agriculture. The Indian Economic Journal, 30(4):835854.

Dwivedi, H. and A. Rudra (1973a). Economic Effects of Tenancy: Some Negative Results, Economic and Political Weekly, 8(28):1239-1246.

Dwivedi, H. and A. Rudra (1973b). Economic Effects of Tenancy: Some Further Negative Results. Economic and Political Weekly, 8(29):1291-1294.

Hallagen, W. (1978). Self Selection by Contractual Choice and the Theory of Sharecropping. Bell Journal of Economics, 9(2):344-354.

Hossain, M. (1977). Farm Size, Tenancy and Land Productivity: An Analysis of Farm Level Data in Bangladesh Agriculture. Bangladesh Development Studies, 5(3):285-348.

Jaynes, G.D. (1982). Production and Distribution in Agrarian Economics, Oxford Economic Papers, 34:346-367.

Johnson, D.G. (1950). Resource Allocation under Share Contracts. Journal of Political Economy, 58(2):111-123.

Kuri, P.K. (2003). Factor Market Imperfections and Explanations of Tenacy: Testing of an Econometric Model using Evidence from Assam of North-East India. Indian Journal of Agricultural Economics, 58(2):234-245.

Laha, A. (2009). Land Tenancy and Rural Credit Market: A Case Study in West Bengal, PhD thesis, The University of Burdwan, West Bengal, India.

Marshall, A. (1890, 1920, 1964). Principles of Economics. London: Macmillan. 
Nabi, I. (1986). Contracts, Resource Use and Productivity in Sharecropping. Journal of Development Studies, 22(2):429-442.

Pant, C. (1980). Exploitation and Interrelated Tenancy and Credit Transactions. Indian Economic Review, 15(4):243-253.

Pant, C. (1983). Tenancy and Family Resources. Journal of Development Economics, 12:27-39.

Rao, C.H.H. (1971). Uncertainty, Entrepreneurship and Sharecropping in India. Journal of Political Economy, 79(3):578-595.

Reid, J.D. (1976). Sharecropping and Agricultural Uncertainty. Economic Development and Cultural Change, 24(3):549-576.

Shaban, R.A. (2000). Testing between Competing Models of Sharecropping. In Readings in Development Economics, Bardhan, P and C. Udry (eds.), II:139-169, MIT Press.

Smith, A. (1776). An Inquiry into the Nature and Causes of Wealth of Nations, New York: Modern Library Edition.

Stiglitz, J.E. (1974). Incentives and Risk Sharing in Sharecropping. Review of Economic Studies, 2(126):219-256.

\section{Appendix: Test Statistics for Productivity Differences}

\section{Case I: Productivity differences in pure owner and pure tenant farms}

We first test whether the variances in the two populations are equal or not. The appropriate test statistic is

$$
\mathrm{M}=\frac{\sum\left(\mathrm{X}_{\mathrm{ij}}-\overline{\mathrm{X}}\right)^{2} / \mathrm{N}_{1}-1}{\sum\left(\mathrm{Y}_{\mathrm{ij}}-\overline{\mathrm{Y}}\right)^{2} / \mathrm{N}_{2}-1}
$$

where, $\mathrm{X}_{\mathrm{ij}}=$ the criterion variable observation for $i$ th crop variety of individual $j$ of the owned land.

$\mathrm{Y}_{\mathrm{ij}}=$ the criterion variable observation for $i$ th crop variety of individual $j$ of the tenanted land.

$\overline{\mathrm{X}}, \overline{\mathrm{Y}}=$ respective sample means of the two types farms.

$\mathrm{N}_{1}, \mathrm{~N}_{2}=$ number of observations in two categories of farms. 
$\mathrm{M}$ is distributed as $\mathrm{F}_{\mathrm{N}_{1}-1, \mathrm{~N}_{2}-1}$ where $\mathrm{N}_{1}-1$ and $\mathrm{N}_{2}-1$ are degrees of freedom, and $\mathrm{N}_{1}$ and $\mathrm{N}_{2}$ are the number of observations in two sub samples. The value of $M$ is to be compared with the tabulated $F_{N_{1}-1, N_{2}-1}$. If $M$ indicates that there is no significant difference between the variances of the two populations, the statistic which is used to test for difference in the population means of the two groups:

$$
\mathrm{S}=\frac{\overline{\mathrm{X}}-\overline{\mathrm{Y}}}{\mathrm{W}} \text { where, } \mathrm{W}^{2}=\left(\frac{1}{\mathrm{~N}_{1}}+\frac{1}{\mathrm{~N}_{2}}\right)\left[\frac{\sum\left(\mathrm{X}_{\mathrm{ij}}-\overline{\mathrm{X}}\right)^{2}+\sum\left(\mathrm{Y}_{\mathrm{ij}}-\overline{\mathrm{Y}}\right)^{2}}{\mathrm{~N}_{1}+\mathrm{N}_{2}-2}\right]
$$

and $\mathrm{S}$ is distributed as $\mathrm{t}$ with $\mathrm{N}_{1}+\mathrm{N}_{2}-2$ degrees of freedom.

On the other hand, if the value of $\mathrm{M}$ indicates that the variances of the two populations are significantly different, for mean difference, the test statistic we shall use is given be Cochran as follows:

$$
\begin{gathered}
\mathrm{V}=\frac{\overline{\mathrm{X}}-\overline{\mathrm{Y}}}{\left[\frac{\mathrm{S}_{1}^{2}}{\mathrm{~N}_{1}}+\frac{\mathrm{S}_{2}^{2}}{\mathrm{~N}_{2}}\right]^{1 / 2}} \\
S_{1}^{2}=\frac{1}{N_{1}-1} \sum\left(X_{i j}-\bar{X}\right)^{2} \text { and } S_{2}^{2}=\frac{1}{N_{2}-1} \sum\left(Y_{i j}-\bar{Y}\right)^{2}
\end{gathered}
$$

$\mathrm{V}$ does not have a $\mathrm{t}$ distribution. However, probabilities for the statistic may be approximated by treating its distribution as a tistribution and by calculating the degrees of freedom. This $\mathrm{V}$ will be compared with

$$
\frac{\frac{\mathrm{S}_{1}^{2}}{\mathrm{~N}_{1}} \cdot \mathrm{t}_{\alpha, \mathrm{N}_{1}-1}+\frac{\mathrm{S}_{2}^{2}}{\mathrm{~N}_{2}} \cdot \mathrm{t}_{\alpha, \mathrm{N}_{2}-1}}{\frac{\mathrm{S}_{1}^{2}}{\mathrm{~N}_{1}}+\frac{\mathrm{S}_{2}^{2}}{\mathrm{~N}_{2}}}
$$

where $\mathrm{t}_{\alpha, \mathrm{N}}$ is the $\alpha$ percent point of Student's ' $\mathrm{t}$ ' with $\mathrm{N}$ degrees of freedom and $\alpha$ has been chosen as 1\% (Diwivedi and Rudra, 1973).

\section{Case II: Productivity differences in owner-cum-tenant farms}

The test statistic relevant for owner-cum-tenant household is

$$
\mathrm{Z}=\frac{\overline{\mathrm{x}}}{\mathrm{s} \sqrt{\mathrm{n}}} \text { where } \overline{\mathrm{X}}=\overline{\mathrm{X}}-\overline{\mathrm{Y}} \text { and } \mathrm{s}^{2}=\frac{\sum\left(\mathrm{x}_{\mathrm{i}}-\overline{\mathrm{x}}\right)^{2}}{\mathrm{n}-1}
$$

Here ' $n$ ' is the number of observations and $s^{2}$ is the unbiased estimator of the population variance. $\mathrm{Z}$ follows ' $\mathrm{t}$ ' distribution with $(\mathrm{n}-1)$ degrees of freedom. 